\title{
The Effectiveness of PSBH (Problem Solving for Better Health and Hospital) Method on Caring Nurse Behavior
}

\author{
$1^{\text {st }}$ Sri Siska Mardiana \\ Medical faculty \\ Muhammadiyah University of Kudus \\ Jawa Tengah Indonesia \\ srisiska@umkudus.ac.id
}

\author{
$2^{\text {nd }}$ Ika Widyawati \\ Department Midwifery \\ Medical faculty \\ Muhammadiyah University of Kudus \\ Jawa Tengah Indonesia
}

\begin{abstract}
Nurse caring behavior is an important aspect in providing nursing care, because it includes human relationships and affects the quality of service and patient satisfaction. Based on interviews and preliminary surveys, it was found that $68 \%$ of patients were not satisfied with nursing services because there were still many nurses who did not show caring behavior. PSBH is a method of solving problems related to nursing services in hospitals. This study aims to analyze the effect of applying the PSBH method to nurses caring behavior in the inpatient room of RSUD dr. R. Soedjati Grobogan Regency and RSUD Kartini Jepara Regency. Method: This research is a quasi-experimental with a pre-test and post-test with control group approach with 38 respondens. This study used purposive sampling with inclusion criteria in both the treatment and control groups. The intervention was use implementation of PSBH metode on caring the patient. The data analysis used $T$ test. The results of the study stated that the average caring behavior of nurses increased in the treatment group by 2.88 from 69.24 to 72.12 . The influence of the application of the PSBH method on nurses caring behavior ( $p$ value 0.000 ). Conclusion: Using of PSBH metode can increase the motivation of caring nurse behaviour.
\end{abstract}

Keywords-PSBH, Metthod, Nurse, Behavior

\section{INTRODUCTION}

Caring is the essence of nursing and is central to nursing practice that is based on the values of kindness, attention, love for yourself and others and respect for the spiritual beliefs of clients. Nurse caring behavior is one of the aspects related to nursing services, because caring includes human relationships and affects the quality of service and patient satisfaction.[1] The study of Shirley et al. In 2012 concerning the level of patient satisfaction in the orthopedic ward with nurses caring at the hospital University of Science Malaysia, found that $82.7 \%$ of respondents were satisfied with nurse services such as respecting patients, calm, gentle, caring, compassion and empathy.[2] The results of research conducted by Abdul, Ariyanti Saleh, and Elly L. Sjattar in the year 2013 concerning the relationship between nurses caring behavior with patient satisfaction shows that $81.3 \%$ of respondents have the perception that nurses have good caring behavior and show satisfaction with nursing services. Based on the above it is very important to take into account the nurse's caring behavior as one of the benchmarks to improve the quality of service in the hospital through efforts to increase patient satisfaction.[3]

Based on data from the assessment results in July 2018 at the Regional General Hospital dr. R. Soedjati Grobogan District obtained client suggestions, including nurses should be more nimble in fulfilling client calls, more friendly, and more polite in dealing with clients and nurses rarely introduce themselves to patients. The results of interviews with several nurses in the inpatient room showed that between the number of nurses and patients was not balanced so that the nurse's workload was felt to be higher, there was no career path, inadequate and nontransparent incentive system and less supervision from management. The results of interviews with the patient's family obtained data that nurses lacked communication, did not mention names and were less friendly. The researchers observed in the inpatient room that nurses rarely greet clients, rarely communicate until interpersonal relationships are established with patients and families. This phenomenon shows that nurses caring behavior has not been implemented well in the Regional General Hospital dr. R. Soedjati Grobogan Regency and need to get serious attention from the management of nursing, so it is necessary to find the cause of the problem why caring behavior can not be maximally carried out in order to find a joint solution between nurses and management.

PSBH (Problem Solving for Better Health and Hospital) can be a sure choice. PSBH is one of the problem solving where in the process it can be applied to overcome health problems but can also be applied to solve individual problems and various other professional activities. How to solve problems done directly. PSBH participants are encouraged to generate new ideas and methods to more effectively utilize available resources to help solve certain 
health problems, the results offered will have a major impact on the progress of nursing performance at the Hospital.[4]Through the stages that exist in the PSBH method including; 1) defining the problem (Define the Problem), 2) prioritizing the problem (Prioritize the Problem), 3) finding a solution (Define the Solution), 4) preparing a plan of activities carefully (creat a good action plan), 5) implementing the activity ( take action) nurses caring problems will be able to be overcome properly. 8 The PSBH approach was first introduced in the United States in 1993. Currently PSBH has developed in 30 countries, including in Africa, India and Mexico. In Indonesia there are around 125 hospitals that have developed the PSBH approach, for example Cipto Mangunkusumo Hospital (Jakarta), Pondok Indah Hospital (Jakarta), Tugu Rejo Hospital Semarang and Banyumas Hospital.[5]

\section{RESEARCH METHODS}

This is a quasi-experimental with one group pre-test post test design by comparing between intervention and

TABLE I. THE CHARACTERISTICS OF RESPONDENT

\begin{tabular}{|c|c|c|c|c|c|}
\hline \multirow[t]{3}{*}{ No } & \multirow{3}{*}{$\begin{array}{c}\text { The Characteristics of } \\
\text { Respondent }\end{array}$} & \multicolumn{4}{|c|}{ Group } \\
\hline & & \multicolumn{2}{|c|}{ Control $(n=38)$} & \multicolumn{2}{|c|}{ Intervention $(n=38)$} \\
\hline & & Frequency & $\%$ & Frequency & $\%$ \\
\hline \multirow[t]{4}{*}{1} & Age & & & & \\
\hline & $20-25$ years old & 17 & 44,7 & 15 & 39,5 \\
\hline & 26-30 years old & 16 & 42,1 & 15 & 39,5 \\
\hline & $>30$ years old & 5 & 13,2 & 8 & 21,0 \\
\hline \multirow[t]{3}{*}{2} & Gender & & & & \\
\hline & Men & 14 & 36,8 & 15 & 39,5 \\
\hline & Women & 24 & 63,2 & 23 & 60,5 \\
\hline \multirow[t]{3}{*}{3} & Education & & & & \\
\hline & Nursing Diploma & 25 & 65,8 & 24 & 63,2 \\
\hline & Nursing Degree & 13 & 34,2 & 14 & 36,8 \\
\hline \multirow[t]{3}{*}{4} & Employee Status & & & & \\
\hline & Permanent & 18 & 47,4 & 20 & 52,6 \\
\hline & Contract & 20 & 52,6 & 18 & 47,4 \\
\hline \multirow[t]{3}{*}{5} & Marital Status & & & & \\
\hline & Married & 15 & 39,5 & 22 & 57,9 \\
\hline & Single & 23 & 60,5 & 16 & 42,1 \\
\hline \multirow[t]{3}{*}{6} & Working periode & & & & \\
\hline & $1-3$ years & 20 & 52,6 & 18 & 47,4 \\
\hline & $>3$ years & 18 & 47,4 & 20 & 52,6 \\
\hline
\end{tabular}

Based on the characteristics of the respondents on the results of the study the average characteristics are almost the same. So if seen from the individual factors that influence caring behavior in both groups is the same. The most age is productive age, namely 25-30 years. At this age individuals tend to be more active in carrying out their work. If you get the right direction and without any pressure at work, the individual will show more achievement in his work. The more mature a person will show the maturity of the soul and be able to think rationally, wisely, and be able to control emotions, and be open to new things.[7]

Caring behavior can be influenced by several factors including individual factors of nurses and psychological factors of nurses and also influenced by organizational control groups. The sampling method used purposive sampling . 11,12 This study used 38 respondents in the intervention group and 38 respondents in the control group. This study conducted in July-August 2018 in RSUD Grobogan dan RSUD Jepara, Central Java and used instrument questioner which modified to determine the motivation of caring nurse behaviour. In the intervention group, respondents given training for 8 hours every day for 2 consecutive days related to the PSBH method. The training began with the presentation by speakers and then was given a Role Play related to PSBH. After that, a group was formed to conduct a discussion to resolve cases using the PSBH method. The data analysis used T-test.

\section{RESULT AND DISCUSSION}

The results of the study include data on the characteristics of respondents, differences in motivation of caring nurse behaviour before and after the intervention, differences in motivation of caring nurse behaviour between the intervention and control groups. factors. Individual factors include demographic factors which include age, sex, length of service, marital status and employment status.[8]There are several things that are included in psychological factors that distinguish in caring behavior including attitudes, perceptions and motivation of nurses to do caring which can be influenced by internal factors and external factors. Based on the results of interviews and observations of respondents in both groups showed almost the same attitude towards caring behavior. Caring behavior is an important thing that supports nursing care but its implementation is influenced by the perceptions and motivations of each individual. In theory, an understanding of good attitudes when performing nursing actions is important because attitudes affect the performance results of nurses.[9] 
TABLE II. THE DIFFERENCES OF CARING NURSE BEHAVIOUR BETWEEN THE INTERVENTION AND CONTROL GROUP BEFORE AND AFTER THE INTERVENTION

\begin{tabular}{|c|c|c|c|c|}
\hline \multirow{3}{*}{$\begin{array}{l}\text { Caring nurse behavior } \\
\text { Variable }\end{array}$} & \multicolumn{4}{|c|}{ Group } \\
\hline & \multicolumn{2}{|c|}{ Intervention $(\mathrm{n}=38)$} & \multicolumn{2}{|c|}{ Control $(\mathrm{n}=38)$} \\
\hline & \begin{tabular}{l|} 
Mean \\
\end{tabular} & $\mathrm{SD}$ & \begin{tabular}{l|} 
Mean \\
\end{tabular} & $\mathrm{SD}$ \\
\hline before & 69,24 & 2,28 & 68,55 & 2,62 \\
\hline After & $\overline{72,12}$ & 2,39 & 69,10 & 2,60 \\
\hline
\end{tabular}

Based on the table II, the average caring behavior of nurses in the treatment group prior to the application of the PSBH method was 69.24 with a standard deviation of 2.28 . While the average score in the control group was 68.55 with a standard deviation of 2.28. The average score in the treatment group and the group shows the category of moderate caring behavior where the average score is categorized $>40=$ bad caring behavior, score $41-70=$ moderate caring behavior, 70-100 = good caring behavior).

Caring is a nurse's attitude in doing her work that has been inherent in a nurse. The practice of caring in nursing shows that nurses work with heart and soul. Caring in nursing care is part of the nurse's performance in caring for patients.[12] Caring behavior is very important in providing nursing care because it can have an impact on increasing client satisfaction. In theory there are three variables that affect nurse performance including individual variables, psychological variables, organizational variables.[13]

Based on these results an increase in nurses caring behavior scores in the treatment group was 2.88. These results indicate an increase in caring behavior into a good caring behavior category. While the average score in the control group was 68.55 with a standard deviation of 2.60. In the control group an increase in the average score of 0.05 was found in the increase in respondents' answers to the questionnaire representing "anticipatory measures" and "monitoring and follow-up of patient health". However, these results do not show an increase in the caring behavior category, which is still in the moderate category. (Average score $>40=$ bad caring behavior, score $41-70=$ moderate caring behavior, $70-100=$ good caring behavior).

Nursing nurses caring behavior in the treatment group after the intervention PSBH (Problem Solving for Better Health and Hospital) has a higher average value which indicates an increase in the category of caring behavior to be better than in the control group where the results show no increase in the caring behavior category (medium category). The results of interviews with nurses said that the existing SPO (Standard Operating Procedure) made nurses confident with the actions taken because there were regulations. Monitoring from hospital supervisors also influences nurses' behaviour.[15]

Factors that influence the performance of nurses namely nurses caring behavior include organizational factors. Organizational culture factors in this case are found in the components of management practice having an important role in changing nurses caring behavior. The influence of management in this component is in the quality control stage of nursing care services (controlling)
.[14] Motivation also affects performance. Motivation is the strength of someone who gives birth to the intensity and perseverance that is done voluntarily. Motivation is an energy that is found in human beings which gives rise to, directs, and organizes behavior. This behavior arises because of internal factors and external factors. Behavior is seen as a reaction or response to a stimulus. Encouragement is activated by the need (need). Needs arouse impulses, and these impulses ultimately activate or bring up behavioral mechanisms.[16]

In general, motivation in both groups was sufficient in carrying out their work as nurses. However, based on the interview the nurse said many factors influence the motivation of nurses when doing nursing care, including the workplace environment, the rules that apply and the rewards provided. This is consistent with theories that affect a person's motivation, namely external factors.[17] The workplace or organizational environment influences nurses' caring behavior. This is what distinguishes nurses caring behavior in the treatment group and the control group. The interview results showed that nurses' motivation in caring generally is influenced by organizational policies or rules that apply in hospitals, including the existence of SPO (Standard Operating Procedures) and rewards (reward system). In general, based on interviews the nurses in the treatment group felt less satisfied with the reward (reward system) prevailing in the hospital, in contrast to the results of the interview in general the nurses in the control group said they were quite satisfied with the existing reward system. In both groups said the existence of SPO (Standard Operating Procedure) for all nursing actions greatly affected the compliance of nurses in taking nursing actions according to the procedure. Based on research there is the influence of organizational factors on caring behavior.[13]

PSBH (Problem Solving for Better Health and Hospitals) can have a positive impact on nurses caring behavior because the stages carried out in PSBH provide an opportunity for individual nurses to be able to identify problems that occur in their own work environment and determine possible solutions and preparation of POA (Plan of Action) and action monitoring. The implementation of the PSBH (Problem Solving for Better Health and Hospital) program is highly dependent on the commitment that exists to each individual nurse both the leader and the executor of nursing. The PSBH program provides nurses with an opportunity to innovate (new and creative ideas), a simple and clear process, using available resources and does not require a lot of money. The principle in this program is that "only you will solve your problem", there 
is no reason not to carry out your activities, and successful activities must be connected, and put human interests first.[9]

The implementation of PSBH (Problem Solving for Better Health and Hospital) in the treatment group has resulted in several things which in the process have received permission and direction and have been standardized by the nursing manager including 7 topics defined in the SOP and 3 topics in the form of socialization. SPOs formed include SPO therapeutic communication techniques, infusion care, effective relaxation, nursing documentation, efficient use of PPE, health education on how to prevent phlebitis in infusion of children by the patient's family, patient preparation for BNO-IVU action, provision of information about facilities, room infrastructure, health education on how to properly wash hands with the baby's mother. Then the socialization that was set was the socialization of the time of drug administration in a timely manner, how to make a proper nursing diagnosis, how to control pain, and the installation of infusions with a sterile principle.[13]

Caring behavior is the core of nursing services. Caring is responsive and responsible in order to meet client expectations. Nurses are the front and closest profession group to the suffering of others, the pain, and misery experienced by the community. Nurses are members of professional groups who use caring expressions that are consistent, frequent, and continuous.[16]

\section{CONCLUSION}

Nurse caring behavior prior to intervention in the control group included moderate caring behavior category, with an average score of 68.55 and in the treatment group included moderate caring behavior category with an average score of 69.24. Nurse caring behavior after intervention in the treatment group increased to good caring behavior category, with an average score of 72.12 with an average score increase of 2.88 points. Using of PSBH methods can increase the motivation of caring nurse behavior.

\section{REFERENCES}

[1] Yuli, Kurnia. Penerapan Metode Problem Solving for Better Health (PSBH) untuk Mengembangkan Proaktifitas Perawat Pelaksana dalam Melaksanakan Operan Pasien di RSUD Tugurejo Semarang. Tidak dipublikasikan. 2009.

[2] Suprihatin. Hubungan Faktor Individu dan Faktor Organisas dengan Perilaku Caring Perawat di Instalasi Rawat Inap RSUD Kota Bandung. Tesis. Program Studi Magister Keperawatan Universitas Indonesia. 2009.

[3] Humas RSUD Sardjito Yogyakarta. Serambi PSBH. Diakses dari Copyright@2013 sardjitohospital.co.id. pada tanggal 12 Desember 2013.

[4] Saleh, Ariyanti et all. Hubungan Perilaku Caring Perawat dengan Tingkat Kepuasan Pasien Rawat Inap Rumah Sakit. Tesis. Program Studi Magister Keperawatan Universitas Hasanuddin. 2012

[5] Watson, J. Carrative Factors, Caritas Process Guide to professional Nursing. Danish Clinical Nursing Journal. 20 (3): 21-7. 2006.

[6] Riani,Budaya Organisasi. Yogyakarta: Graha Ilmu. 2011.

[7] Zulfikar,Pengaruh Budaya Organisasi dan Kepuasan Kerja Terhadap Motivasi Kerja Perawat di Rumah Sakit Tk. II Kesdam I/BB tahun 2004 On available from: http://repository.usu.ac.id/handle/123456789/33336. diakses tanggal 27 januari 2014.

[8] Rivai, V. Manajemen Sumber Daya Manusia untuk Perusahaan dari Teori ke Praktek. Jakarta: Rajawali Pers. 2011.

[9] Bertolino, Truxillo, \& Fraccarolly. Age as Moderator of The Relationship of Proactive Personality with Training Motivation, Perceived Career Development for Training and Training Behavioral Intentions. Journal of Organizationere Behavior. Vol 32. Pages 248-263. 2011

[10] Kelana, Kusuma. Metodologi Penelitian Keperawatan. Jakarta : Trans Info Media. 2011.

[11] Masyhuri \& Zaenuddin, M. Metodologi Penelitian Pendekatan Praktis dan Aplikatif. Cetakan pertama. Bandung : P.T. Refika Aditama. 2008

[12] Fitzpatrick, J \& Hoyt, P. Problem Solving for Better HealthNursing: Application of An Internationally Tested Model To Nursing Schools in The United State. Journal of Professional Nursing. 20(1). hlm 1-12. 2013

[13] Mazidawati. Effect of The Implementation of Problem Solving for Better Health (PSBH) Toward The Documentation of Nursing Care. Indian Journal of Research.hlm 108-110. 2018.

[14] Nursalam. Manajemen Keperawatan Aplikasi dalam Praktek Keperawatan Profesional (5rd ed.). Jakarta. Salemba Medika. 2016.

[15] Dreyfus Health Foundation. Problem Solving for Better Health, Newyork, Edisi Bahasa Indonesia, dikembangkan Pusat Penelitian Keluarga Sejahtera (PUSKA UI). 2017

[16] Sugandi, P.. Efektivitas Problem Solving for Better Health (PSBH) terhadap Kelengkapan Dokumentasi Asuhan Keperawatan di RSU Dr. Pirngadi Medan. Tesis. Universitas Sumatera Utara.2015

[17] Tatiana Siregar, Misparsih Misparsih, Jaenudin Saputra, Studi Kasus: Penerapan Health Education di RSU Kabupaten Tangerang sebagai Hasil dari Problem Solving for Better Health (PSBH). 2018egara: Catatan Kekerasan terhadap Perempuan," Catatan Tahunan Tentang Kekerasan Terhadap Perempuan. Jakarta, hal. 55, 2019. 